\title{
Seasonal variation of physicochemical factor and fecal pollution in the Hansan- Geojeman area, Korea
}

\author{
Young Cheol Park', Poong Ho Kim², Yeoun Joong Jung ${ }^{1}$, Ka Jeong Lee', Min Seon Kim, Kyeong Ri Go', \\ Sang Gi Park', Soon Jae Kwon ${ }^{1}$, Ji Hye Yang ${ }^{1}$ and Jong Soo Mok ${ }^{1 *}$
}

\begin{abstract}
The seasonal variation of fecal coliforms (FCs) and physicochemical factors was determined in seawaters of the Hansan-Geojeman area, including a designated area for oyster, and in inland pollution sources of its drainage basin. The mean daily loads of FCs in inland pollution sources ranged from $1.2 \times 10^{9}$ to $3.1 \times 10^{11}$ most probable number (MPN)/day; however, the pollutants could not be reached at the designated area. FC concentrations of seawaters were closely related to season, rainfall, and inland contaminants, however, within the regulation limit of various countries for shellfish. The highest concentrations for chemical oxygen demand (COD) and chlorophyll-a in seawaters were shown in the surface layer during August with high rainfall, whereas the lowest for dissolved oxygen (DO) in the bottom layer of the same month. Therefore, it indicates that the concentrations of FC, COD, DO, and chlorophyll- $a$ of seawaters were closely related to season and rainfall.
\end{abstract}

Keywords: Fecal coliform, Physicochemical factor, Hansan-Geojeman area, Inland pollutant, Seawater

\section{Background}

The Hansan-Geojeman area is located between the Geoje and Hansan islands in Gyeongnam province on the south coast of Korea (Fig. 1). The sea surface area is about $55 \mathrm{~km}^{2}$, and the longest length of the east-west or south-north is about $10 \mathrm{~km}$. The drainage basin of the Hansan-Geojeman area is $161.8 \mathrm{~km}^{2}$, and most parts are farmlands and mountains. Approximately 17,550 people lived in this drainage area in 2012. Of the area, $72.3 \%$ $\left(116.9 \mathrm{~km}^{2}\right)$ was occupied by forestry field and its $18.5 \%$ was cultivated as both of rice paddy and dry paddy (Yoo et al. 2013). The Hansan-Geojeman area has been a designated shellfish-growing area for export since 1974 because it is a major oyster production area in Korea (Ha et al. 2011). According to Statistics Korea (2013), Korea produced 239,779 tons of oysters, the first largest amount of shellfish produced in Korea. In particular, Gyeongnam province, including the Hansan-Geojeman

\footnotetext{
* Correspondence: mjs0620@korea.kr

${ }^{1}$ Southeast Sea Fisheries Research Institute, National Fisheries Research \& Development Institute, 397-68, Sanyang-iljuro, Sanyang-up, Tongyeong 650-943, Republic of Korea

Full list of author information is available at the end of the article
}

area, produced the largest amount of oysters in Korea, accounting for about $90 \%$ of oyster products. The products are consumed domestically or exported mainly to the USA, Japan, and the European Union (EU) (Mok et al. 2013, 2014a, 2015). The Korean government has established a memorandum of understanding with the USA and EU, and there are designated shellfish-growing areas for export along the southern coast of Korea that meet the standards set by these countries (Mok et al. 2014b, 2015). In particular, oysters are commonly consumed raw in many cultures, including Korea. Therefore, the sanitary status of seawaters in this area is needed to assess oyster quality both for Korean populations and for consumers in importing countries.

Fecal or chemical contaminations of inland and coastal waters may have a negative impact on shellfish sanitary status (Feldhusen 2000; Dorfman and Sinclair Rosselot 2008) resulting in economic losses due to shellfish bed closures (Rabinovici et al. 2004). The pollutions can also deteriorate the aquatic environment for producing, harvesting, and consuming shellfish. To protect public health, the authorities in various countries, such as Korea, the USA, and EU, have established regulatory limits and 


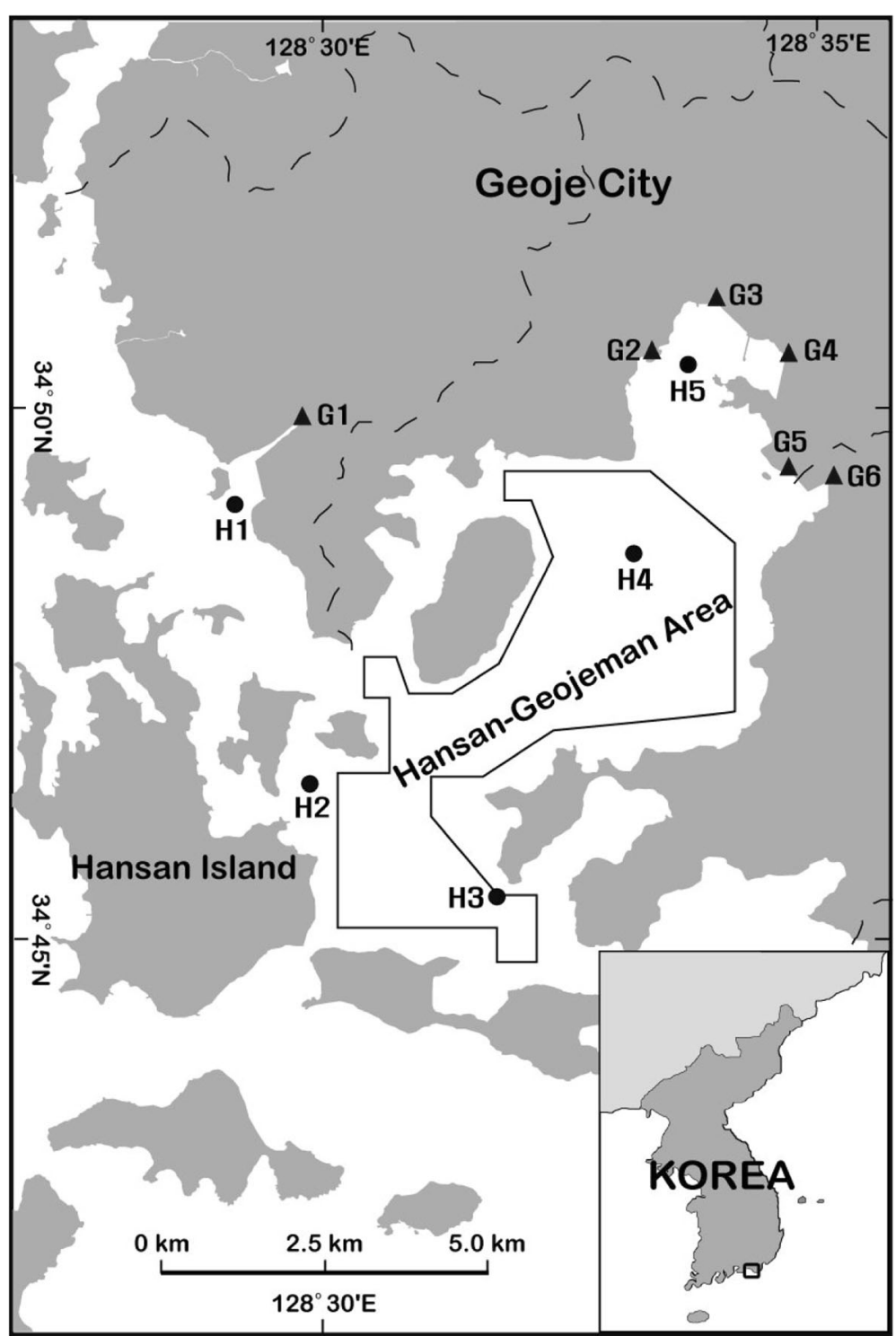

Fig. 1 Sampling locations of inland pollution sources and seawaters from the Hansan-Geojeman area on the southern coast of Korea

monitoring programs using the fecal coliforms (FCs) for bivalves or their growing area (EC 2005; US FDA 2013; KMFDS 2015; MOF 2015). Impact of inland pollution sources on water quality of shellfish-growing areas must also be estimated regularly for identifying pollution sources and protecting the growing area.

In the present study, we determined the concentrations of FCs and physicochemical factors in the seawaters collected from the Hansan-Geojeman area on the southern coast of Korea. In addition, we also attempt to compare the spatial and seasonal variation of FCs and physicochemical factors of major inland pollution sources in the drainage basin of this area. To our knowledge, this is the first report on the comparison and contribution of FCs and physicochemical factors of inland pollution sources discharged to the Hansan-Geojeman area of Korea.

\section{Methods}

\section{Sample collection}

The sampling locations for creek water and seawater from the Hansan-Geojeman area on the southern coast of Korea, where a designated shellfish-growing area for export was located, are presented in Fig. 1. Creek water samples were collected at low tide in 2014 from the six fixed sampling stations, classified as major inland pollution sources, in the drainage area of the Hansan-Geojeman area to evaluate the effects of inland pollution sources on water quality of the shellfish-growing area. The samples of surface seawater for fecal pollution-indicative bacteria 
were collected once a month in 2014 at the five fixed stations in the surveyed area. Seawater samples for physicochemical factors were also collected bimonthly in 2014 from the surface and bottom layers of water using a Niskin water sampler at the same stations for fecal pollution-indicative bacteria. Samples were maintained below $10{ }^{\circ} \mathrm{C}$ during transport to the laboratory.

\section{Physicochemical factor analysis}

Physicochemical factors included temperature, salinity, $\mathrm{pH}$, dissolved oxygen (DO), dissolved inorganic nutrients, and chemical oxygen demand (COD), as well as a biological factor, chlorophyll- $a(\mathrm{Chl}-a)$. The measurement methods are as follows. Temperature, salinity, $\mathrm{pH}$, and $\mathrm{DO}$ values were observed on-site using a YSI 556 multiprobe system (Yellow Springs, OH, USA). They were completely processed on-site before being transported to the laboratory. Dissolved inorganic nutrients, COD, and Chl- $a$ were analyzed according to the Marine Environmental Process Exam Standards (MOF 2002). Dissolved inorganic nutrients were analyzed by filtering the sample through a $0.45-\mu \mathrm{m}$ membrane filter paper (nitrate cellulose), then measuring ammonia nitrogen $\left(\mathrm{NH}_{3}\right)$, nitrate nitrogen $\left(\mathrm{NO}_{3}\right)$, and nitrite nitrogen $\left(\mathrm{NO}_{2}\right)$, and dissolved inorganic phosphate (DIP) using a nutrient auto-analyzer (Quattro four-channel, Seal Analytical, WI, USA). Dissolved inorganic nitrogen (DIN) was expressed as the sum of $\mathrm{NH}_{3}, \mathrm{NO}_{3}$, and $\mathrm{NO}_{2}$. Chl- $a$ was measured by filtering $500 \mathrm{~mL}$ of the sample through a $0.45-\mu \mathrm{m}$ membrane filter paper, then extracting the color dye with $90 \%$ acetone in a cold darkroom, and using a fluorescence spectrometer (10-AU, Turner Designs, CA, USA). COD of seawater was analyzed with the alkaline permanganate method on non-filtered samples.

\section{Fecal pollution-indicative bacteria analysis}

The bacteriological examination of water samples were immediately performed after receiving. The numbers of FC in the samples were examined according to the recommended procedures for the examination of seawater and shellfish (APHA 1970). FC counts were determined by a multiple dilution series using the most probable number (MPN) method. Five tubes were used for each dilution. Lauryl tryptose broth (Difco, Detroit, MI, USA) was used as the presumptive medium. The culture tubes of presumptive positive, in which gas formed within $48 \mathrm{~h}$ after inoculation at $35.0{ }^{\circ} \mathrm{C}$, were confirmed for $\mathrm{FC}$ using an EC medium (Difco) at $44.5{ }^{\circ} \mathrm{C}$. FC populations were expressed as MPN per $100 \mathrm{~mL}$.

\section{Evaluation of inland pollution source}

The flow velocity of discharges from inland pollution sources was measured on-site using a hydrometer
(Flo-Mate 2000, Marsh McBirney, Loveland, CO, USA) for their flow rate, which was calculated using the velocity-area method. Evaluation method of pollution sources is suggested in the US Food and Drug Administration (FDA) in accordance with the following equations (Park et al. 2012; Shim et al. 2012). Thus, it is calculated as the amount of dilution water required that can dilute the FC density to less than $14 \mathrm{MPN} / 100 \mathrm{~mL}$ of the standard level in the seawater based on the US FDA guidance.

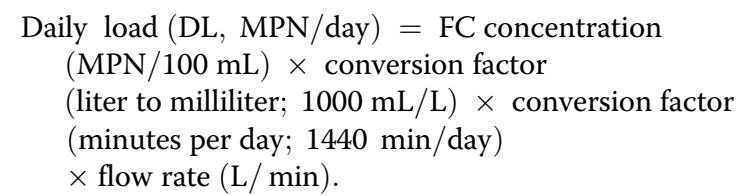
Dilution water required (DWR, $\mathrm{m}^{3} /$ day $)=\mathrm{DL}$ (MPN/day)/ (standard [14 MPN/100 mL] $\times$ conversion factor [milliliter to cubic meter; $\left.\left.\mathrm{m}^{3} / 1,000,000 \mathrm{~mL}\right]\right)$.

Area required $\left(\mathrm{AR}, \mathrm{m}^{2} /\right.$ day $)=\mathrm{DW}$
$\mathrm{R}\left(\mathrm{m}^{3} /\right.$ day $) /$ average depth $(\mathrm{AD}, \mathrm{m})$.

Radius of half-circle $(\mathrm{m} /$ day $)=$ square root $\left(\operatorname{AR}\left[\mathrm{m}^{2} /\right.\right.$ day $\left.] \times 2 / 3.14\right)$.

\section{Statistical analysis}

Statistical evaluation was conducted using analysis of variance with the general linear model procedure (SAS version 9.2, SAS Institute, Cary, NC, USA). Duncan's multiple-range test was applied to determine the significance of differences between the concentrations of FCs or physicochemical factors.

\section{Results and discussion}

\section{Concentration of FCs in inland pollution sources}

The concentrations, daily loads, and diffusion ranges of FC in the major inland pollution sources collected from six fixed stations at the drainage area of the HansanGeojeman area in 2014 are shown in Fig. 2. Nonpoint source (NPS) pollution occurs when rainfall, snowmelt water, or irrigation water flows over land, carrying and depositing pollutants into streams, lakes, and coastal waters (Wu and Chen 2013). The level of bacterial indicator may be influenced by rainfall events, and therefore, rainfall is often not considered when monitoring the microbial quality of waters (Lipp et al. 2001; Rose et al. 2001). Therefore, this survey was conducted when no precipitation occurred during a week before the sampling for minimizing NPS inputs into the inland pollution sources.

In the six inland water samples, the mean flow rates at each station ranged from 43 to $4529 \mathrm{~L} / \mathrm{min}$; the highest mean value was found at station G6, which is a Sanyang stream in Geoje city (Fig. 2a). Specially, the highest 

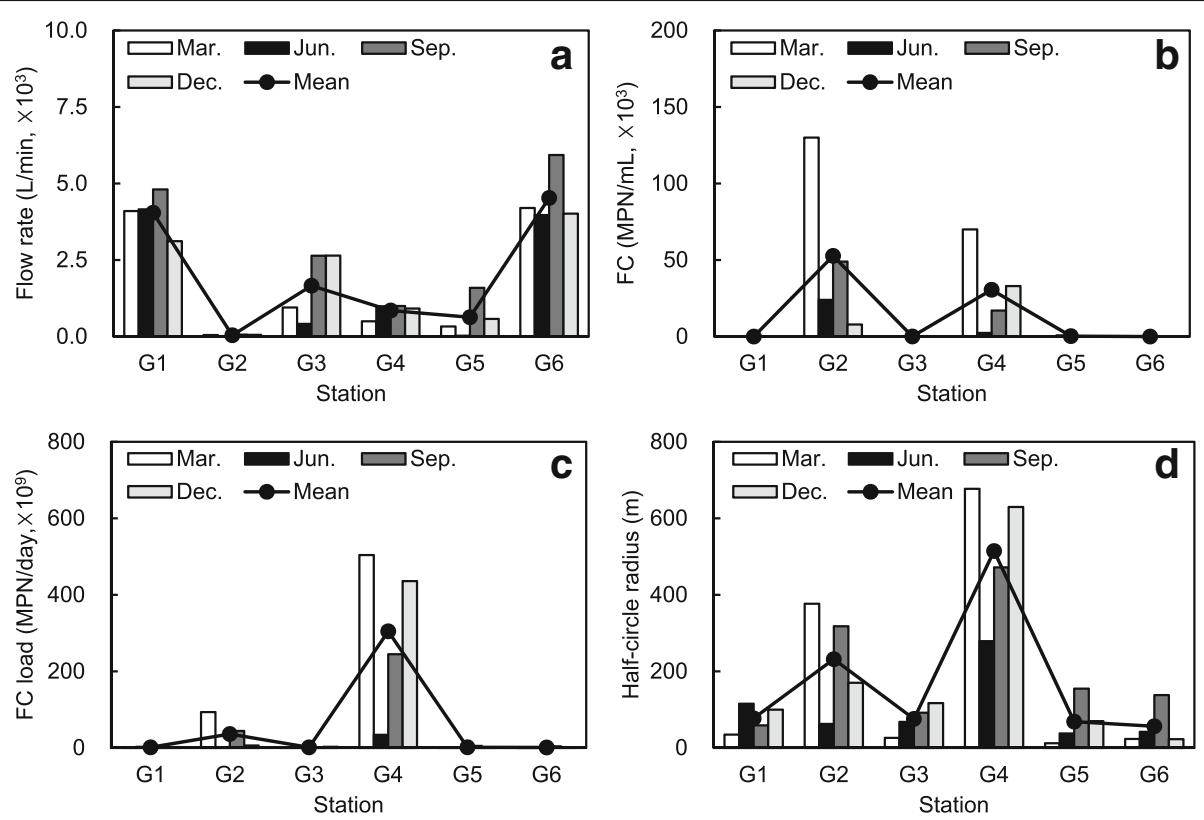

Fig. 2 Spatial and seasonal variation of flow rates (a), fecal coliform (FC) concentrations (b), daily loads of FC (c), and half-circle radii of FC (d) of discharges from major inland contamination sources in the drainage area of the Hansan-Geojeman area, Korea

values of flow rate at all the stations were found in September. It is presumed that rainwater was largely stored in reservoirs or streams during the summer season with heavy rainfall and used for rice farming between July and September. FC concentrations of major pollution sources ranged from 2.0 to $130,000 \mathrm{MPN} / 100 \mathrm{~mL}$; the highest level was found in March at station G2, which is a Neagan stream in Geoje city (Fig. 2b). It is presumed that the stream is surrounded by dry fields and orchards on which fertilizers including animal feces are spread during spring season in Korea.

According to the formula in the "Methods" section, the mean daily loads of FC at each station ranged from $1.2 \times 10^{9}$ to $3.1 \times 10^{11} \mathrm{MPN} /$ day (Fig. 2c). The mean half-circle radii of discharges at each site on the sea area ranged from 56.6 to $514.5 \mathrm{~m}$; the highest radius was found at station G4, which is a Seojeong stream (Fig. 2d), because of the relatively high FC concentration of that, which flows through a relatively densely populated residential area into the sea area. However, the pollutants could be not reached at the boundary line of the designated area because of the buffer zone between shoreline and boundary line of the designated area.

\section{Distributions of FCs and bacteriological water quality}

FC concentrations of seawater samples in 2014 from the five stations fixed in the Hansan-Geojeman area, including a designated area for oyster, are summarized in Fig. 3. The monthly values of geometric mean for FC ranged from <1.8 to $46.0 \mathrm{MPN} / 100 \mathrm{~mL}$; the maximum level was found in August (Fig. 3a). Monthly rainfall of Geoje city
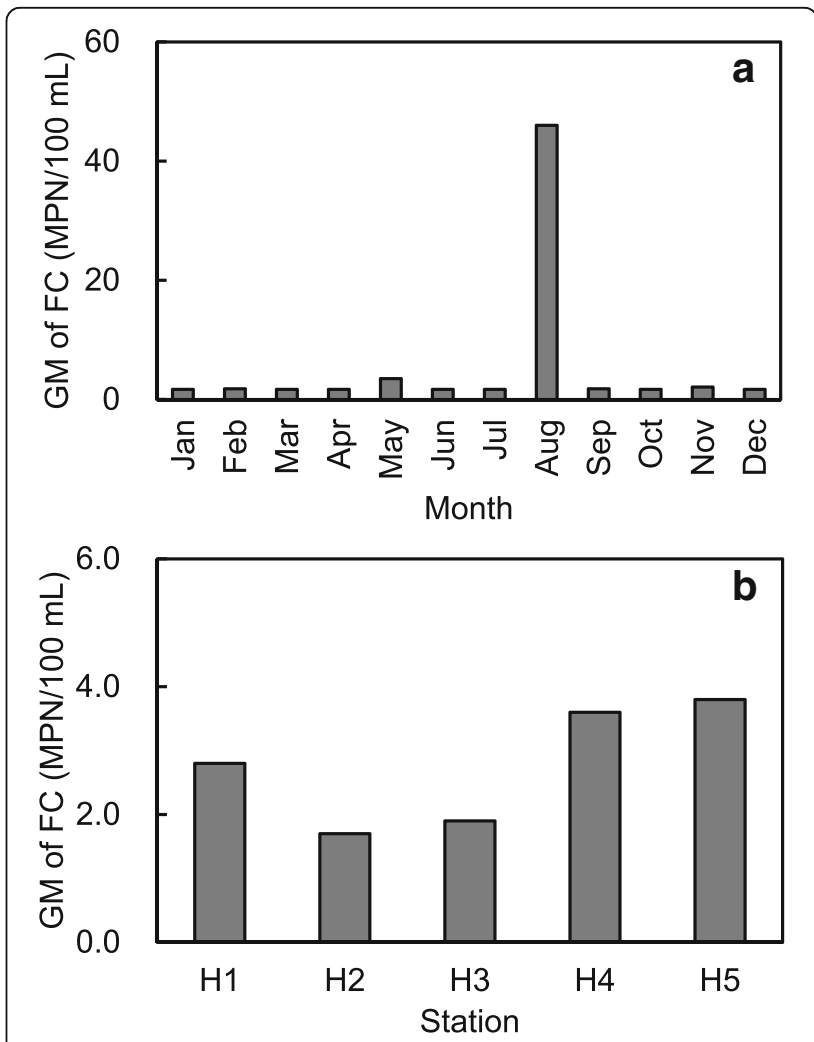

Fig. 3 (a, b) Spatial and seasonal variation of the geometric mean (GM) of fecal coliform (FC) for seawater samples collected from the Hansan-Geojeman area, Korea, in 2014 
in 2014 varied from 13.1 to $589.4 \mathrm{~mm}$ with seasonal variation (data not shown). The highest value found in August was about fourfold higher than monthly mean rainfall in 2014. In particular, the samples were collected after approximately 200-mm rainfall in August 2014. Seasonal temperature variation may affect the abundance of bacteria (Rippey 1994). Avila et al. (1989) reported that microbial counts were twofold higher in fall and spring and around eightfold higher in summer than in winter during the monitoring of seawater quality on the southern coast of Spain. Chigbua et al. (2004) also reported that FC levels had a positive relationship with rainfall in Mississippi Sound. This study also shows a similar result that FC concentrations were relatively detected higher in August than in other seasons and affected greatly by rainfall. Therefore, it indicates that FC counts had a seasonal variation and, specially, were detected higher after a heavy rainfall before the sampling day. But, because the oyster harvesting period in Korea is from October to May in the following year, oysters are not fortunately harvested in the summer season with heavy rainfall.

Additionally, the values of geometric mean for $\mathrm{FC}$ at each station ranged from $<1.8$ to $3.8 \mathrm{MPN} / 100 \mathrm{~mL}$; the highest value was found at site $\mathrm{H} 5$ (Fig. 3b), which is close to that of major pollution sources (G2 and G4) with high concentration and daily load of FC (Fig. 2). It was found that the high geometric mean level of FC in August 2014 was caused by FC (920 MPN/100 mL) of a sample collected after rainfall at site $\mathrm{H} 5$, which is close to that of waste discharges from the sites G2 and G4 along the shoreline with a populated residential area (Fig. 1). The stations G2 and G4 for pollution source had high concentration and daily load of FC in March (Fig. 2); however, the $\mathrm{FC}$ value at site $\mathrm{H} 5$ was low in the same month without rainfall before sampling (Fig. 3a). In this study, all stations showed the values far below the regulation limit (14 MPN/100 mL) of geometric mean value for FC set by Korea (MOF 2015), the USA (US FDA 2013), and New Zealand (NZFSA 2006).

\section{Concentration of physicochemical factors in inland pollution sources}

The concentrations and daily loads of COD, DIN, and DIP in the major inland pollution sources, collected quarterly from the six fixed stations at the drainage area of the Hansan-Geojeman area, are shown in Figs. 4 and 5, respectively. This survey was also conducted when no precipitation occurred during a week before the sampling for minimizing NPS inputs into the inland pollution sources. COD concentrations of the pollution sources ranged from 2.4 to $6.9 \mathrm{mg} / \mathrm{L}$; the highest level was found at station G4, which is a Seojeong stream in Geoje city (Fig. 4a), whereas the daily loads of COD at each station
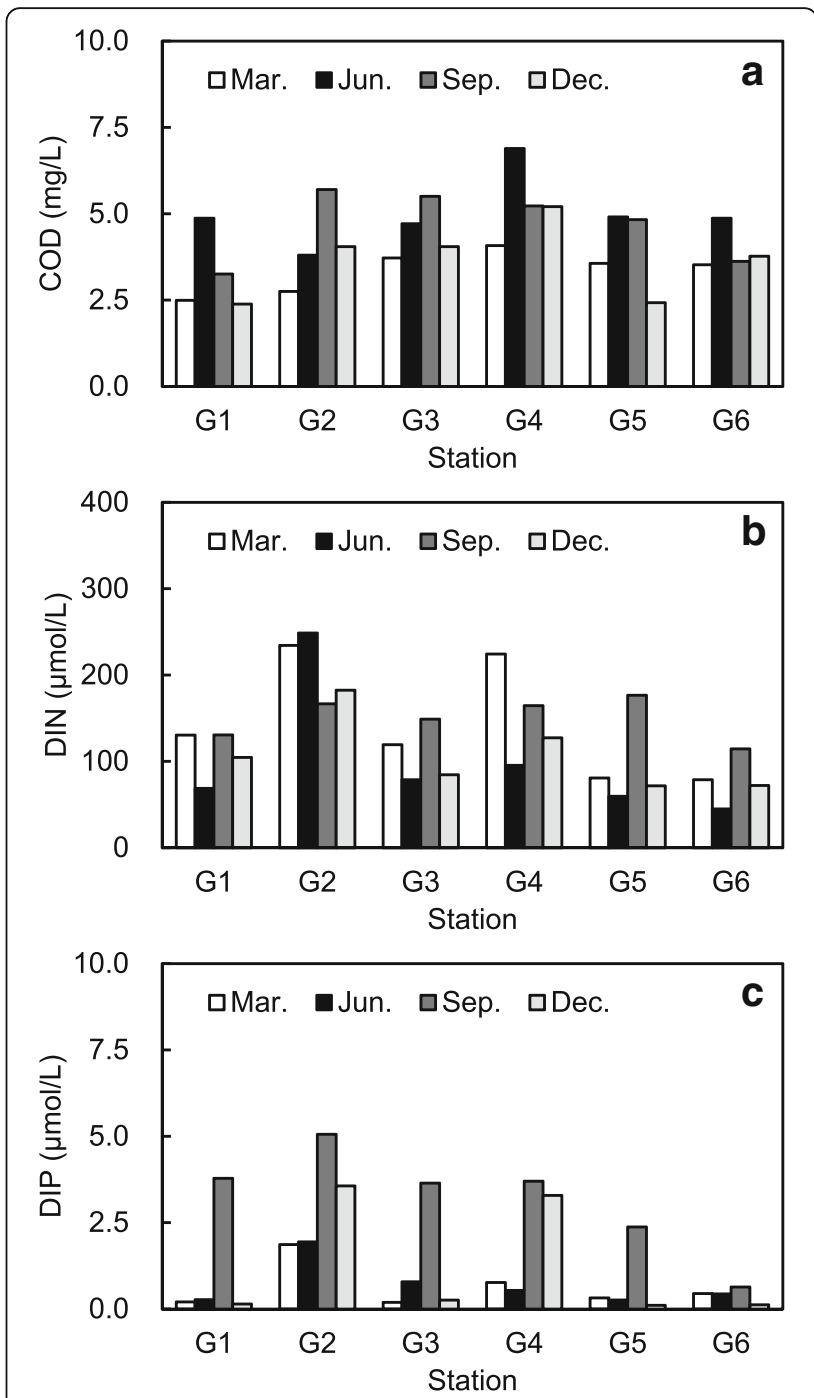

Fig. 4 Spatial and seasonal variation of chemical oxygen demand (COD) (a), dissolved inorganic nitrogen (DIN) (b), and dissolved inorganic phosphate (DIP) (c) of discharges from major inland contamination sources in the drainage area of the Hansan-Geojeman area, Korea

ranged from $1.4 \times 10^{5}$ to $3.1 \times 10^{8} \mathrm{mg} /$ day; higher values were found at stations G1 and G6 (Fig. 5a) with a relatively high flow rate (Fig. 2a). In addition, DIN and DIP concentrations of pollution sources ranged from 45 to $249 \mu \mathrm{mol} / \mathrm{L}$ and 0.11 to $5.06 \mu \mathrm{mol} / \mathrm{L}$, respectively; the highest levels were found at station G2, which is a Naegan stream in Geoje city (Fig. 4b, c); however, the daily loads of DIN and DIP were the lowest at site G2 with relatively much low flow rate (Fig. 5b, c). The concentrations of DIP were relatively higher in September than in other months surveyed in this study. It assumes that artificial fertilizer including phosphate is largely spread on rice fields between July and September in Korea; Geoje city supplied 946 tons of artificial fertilizer including 177 tons of 


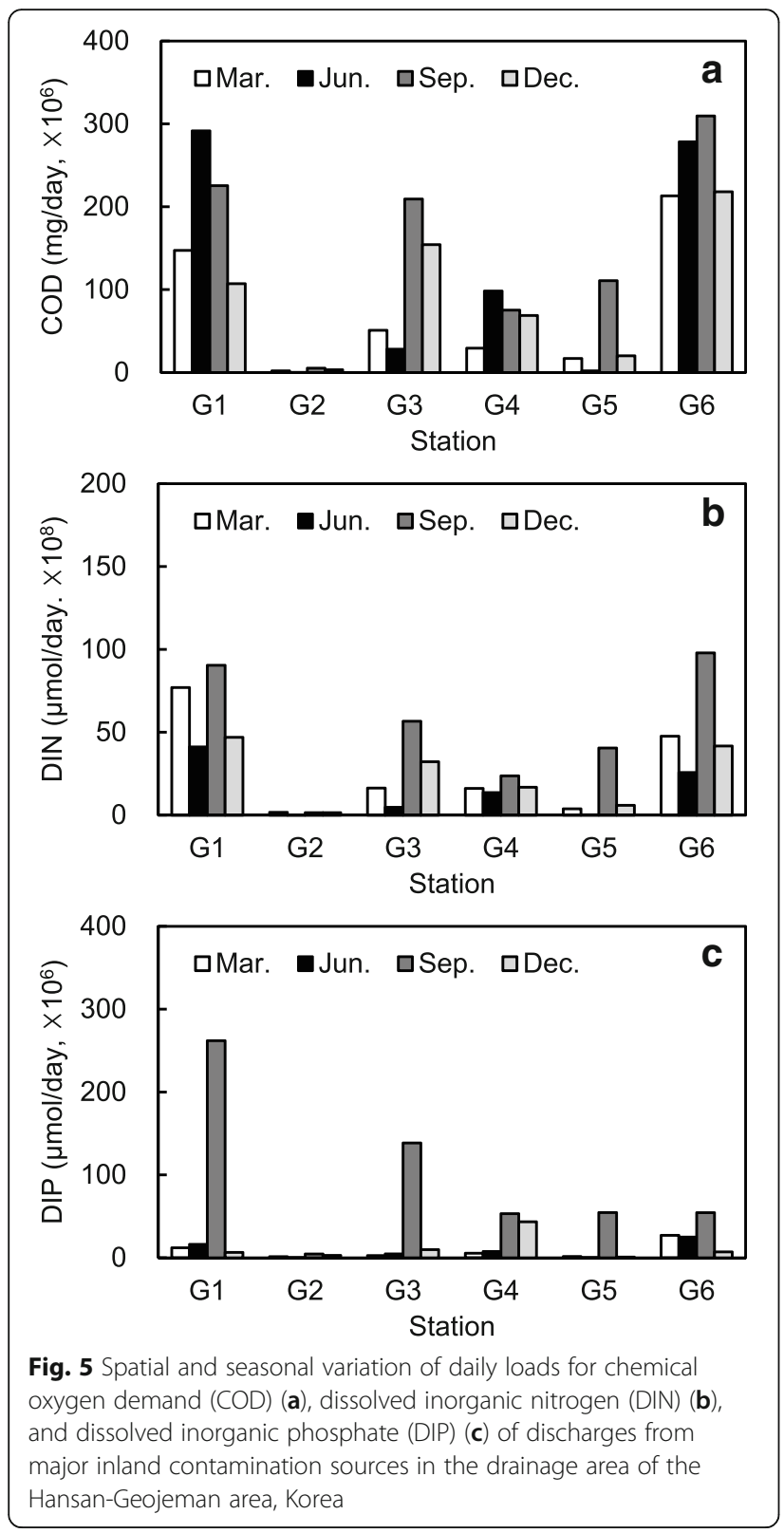

phosphate in 2013 (Geoje city 2014). The daily loads of DIN and DIP were relatively higher in September than in other months because of relatively high flow rates and/or concentrations (Figs. 2a and $4 \mathrm{~b}, \mathrm{c}$ ). In particular, the daily load of DIP was very high in September at stations G1 and G3, which are surrounded by a lot of rice fields.

Moreover, a significant relationship was identified between FC and DIN concentrations in the major inland pollution sources $(p<0.05)$; the correlation coefficients $\left(R^{2}\right)$ were 0.60 , indicating close correlation with both FC and DIN (Fig. 6). The FC concentrations did not show almost the correlation with COD and DIP concentrations in the inland pollutions.
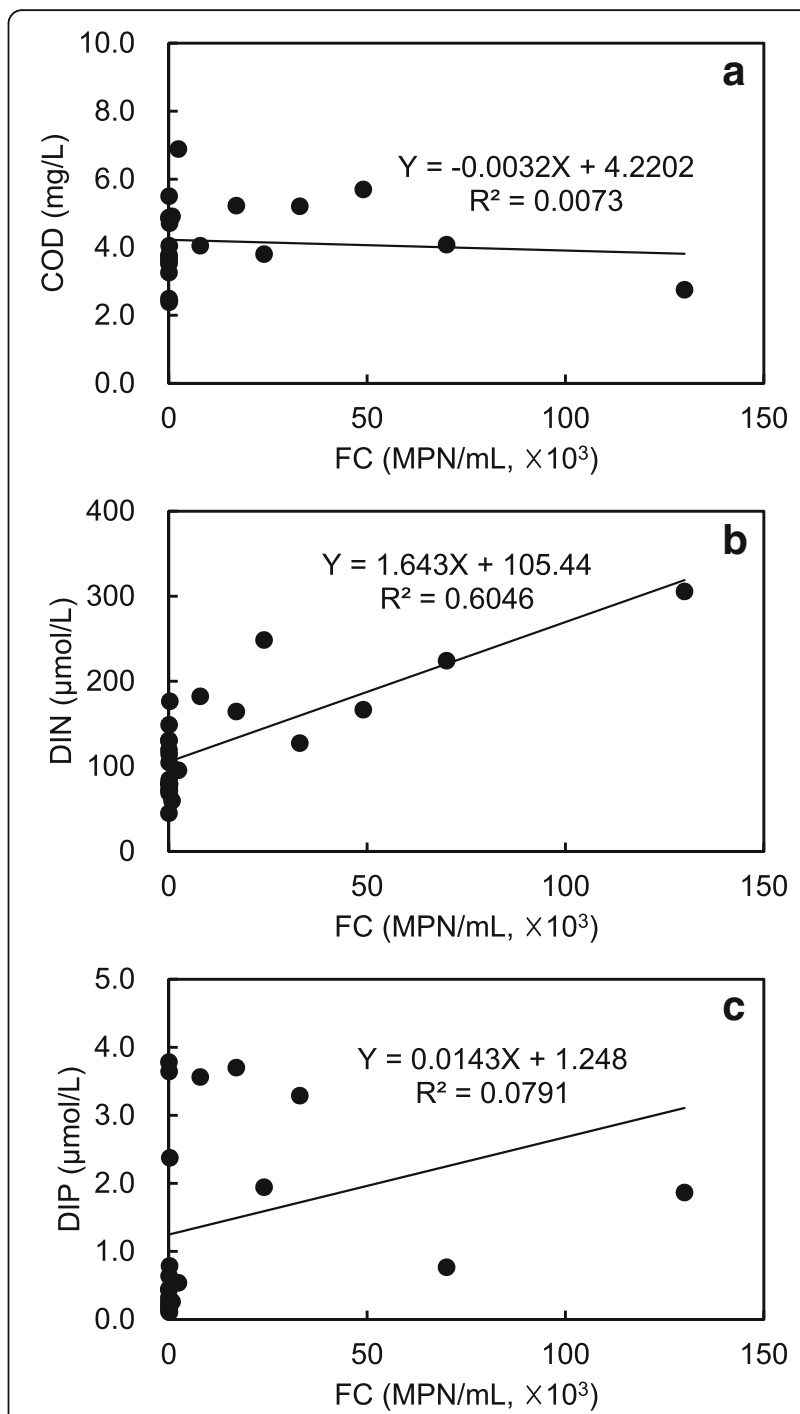

Fig. 6 Concentration distribution of chemical oxygen demand (COD) (a), dissolved inorganic nitrogen (DIN) (b), and dissolved inorganic phosphate (DIP) (c) based on fecal coliform (FC) concentration of inland contamination sources in the drainage area of the Hansan-Geojeman area, Korea

\section{Distributions of physicochemical factors in seawaters}

The concentration distribution of physicochemical factors of seawater samples collected from the surface and bottom layers of the Hansan-Geojeman area is shown in Tables 1 and 2 and Fig. 7. All physicochemical parameters tended to show low difference between the surface and bottom layers during December. Mean water temperatures were within the range of 9.02 to $25.59{ }^{\circ} \mathrm{C}$ at the surface layer, and 8.95 to $21.12{ }^{\circ} \mathrm{C}$ at the bottom layer, with the largest temperature difference between the layers recorded in August (approximately $4.5^{\circ} \mathrm{C}$ ). Monthly mean surface salinity varied from 29.47 to 34.15 with seasonal variation. Because of heavy rainfall during wet season in Korea, August had the lowest salinity value of 29.47 at the 
Table 1 Values of temperature, salinity, pH, dissolved oxygen (DO), chemical oxygen demand (COD), and chlorophyll-a in surface and bottom waters of the Hansan-Geojeman area, Korea, in 2014

\begin{tabular}{cllllll}
\hline Month & Temperature $\left({ }^{\circ} \mathrm{C}\right)$ & Salinity & $\mathrm{pH}$ & $\mathrm{DO}(\mathrm{mg} / \mathrm{L})$ & $\mathrm{COD}(\mathrm{mg} / \mathrm{L})$ & Chlorophyll-a $(\mu \mathrm{g} / \mathrm{L})$ \\
\hline Surface & & & & & & \\
Feb. & $9.02 \pm 1.04$ & $34.15 \pm 0.09$ & $8.22 \pm 0.07$ & $10.36 \pm 0.58$ & $1.92 \pm 0.15$ & $7.51 \pm 4.01$ \\
Apr. & $13.26 \pm 0.36$ & $33.84 \pm 0.31$ & $8.19 \pm 0.04$ & $8.38 \pm 0.14$ & $1.67 \pm 0.54$ & $1.33 \pm 0.37$ \\
Jun. & $18.52 \pm 0.31$ & $33.85 \pm 0.04$ & $7.92 \pm 0.04$ & $7.95 \pm 0.35$ & $1.54 \pm 0.29$ & $2.87 \pm 1.25$ \\
Aug. & $25.59 \pm 0.71$ & $29.47 \pm 2.49$ & $8.32 \pm 0.28$ & $6.50 \pm 1.71$ & $2.20 \pm 0.98$ & $18.03 \pm 14.28$ \\
Oct. & $19.90 \pm 0.48$ & $32.73 \pm 0.22$ & $8.13 \pm 0.02$ & $7.27 \pm 0.71$ & $2.31 \pm 0.18$ & $9.47 \pm 1.87$ \\
Dec. & $14.68 \pm 0.47$ & $33.30 \pm 0.30$ & $8.11 \pm 0.02$ & $7.56 \pm 0.25$ & $1.57 \pm 0.23$ & $3.50 \pm 2.66$ \\
Bottom & & & & & & \\
Feb. & $8.95 \pm 0.96$ & $34.18 \pm 0.08$ & $8.23 \pm 0.06$ & $10.00 \pm 0.51$ & $2.04 \pm 0.32$ & $5.64 \pm 3.03$ \\
Apr. & $12.96 \pm 0.12$ & $34.06 \pm 0.09$ & $8.20 \pm 0.04$ & $8.63 \pm 0.29$ & $2.10 \pm 0.26$ & $2.71 \pm 1.76$ \\
Jun. & $17.04 \pm 0.49$ & $34.09 \pm 0.05$ & $7.96 \pm 0.03$ & $7.85 \pm 0.24$ & $1.93 \pm 0.41$ & $1.52 \pm 0.22$ \\
Aug. & $21.12 \pm 2.28$ & $33.47 \pm 0.42$ & $8.04 \pm 0.04$ & $4.38 \pm 0.28$ & $2.32 \pm 0.30$ & $11.09 \pm 11.40$ \\
Oct. & $19.85 \pm 0.48$ & $32.84 \pm 0.09$ & $8.10 \pm 0.02$ & $7.05 \pm 0.56$ & $2.49 \pm 0.37$ & $10.50 \pm 5.25$ \\
Dec. & $14.69 \pm 0.48$ & $33.16 \pm 0.21$ & $8.11 \pm 0.02$ & $7.38 \pm 0.66$ & $1.50 \pm 0.39$ & $4.48 \pm 3.25$ \\
\hline
\end{tabular}

Values are means \pm standard deviations

surface layer and the largest difference between the surface/bottom layers, with 4.0. But the differences of water temperature and salinity among the sampling stations were not significant (data not shown).

Besides, COD, which is comparatively sensitive to the inflow of terrestrial contaminants, showed the largest difference at station $\mathrm{H} 1$ in August, when there is high rainfall. $\mathrm{COD}$ in the surface layer was also highest at station $\mathrm{H1}$

Table 2 Concentrations of dissolved inorganic nutrients in surface and bottom waters of the Hansan-Geojeman area, Korea, in 2014

\begin{tabular}{clllll}
\hline Month & \multicolumn{5}{l}{ Concentrations of dissolved inorganic nutrients ( $\mu \mathrm{mol} / \mathrm{L})$} \\
\cline { 2 - 6 } & $\mathrm{NH}_{3}$ & $\mathrm{NO}_{2}$ & $\mathrm{NO}_{3}$ & $\mathrm{DIN}$ & $\mathrm{DIP}$ \\
\hline Surface & & & & & \\
Feb. & $1.28 \pm 0.31$ & $0.12 \pm 0.04$ & $2.48 \pm 0.96$ & $3.59 \pm 1.24$ & $0.18 \pm 0.08$ \\
Apr. & $1.30 \pm 0.56$ & $0.10 \pm 0.03$ & $0.91 \pm 0.47$ & $2.30 \pm 1.02$ & $0.22 \pm 0.11$ \\
Jun. & $1.90 \pm 1.18$ & $0.18 \pm 0.08$ & $1.53 \pm 0.68$ & $3.60 \pm 1.91$ & $0.20 \pm 0.12$ \\
Aug. & $1.60 \pm 0.78$ & $0.38 \pm 0.18$ & $3.89 \pm 1.36$ & $5.88 \pm 1.84$ & $0.31 \pm 0.14$ \\
Oct. & $5.30 \pm 2.00$ & $0.74 \pm 0.20$ & $2.06 \pm 0.46$ & $8.10 \pm 2.60$ & $0.61 \pm 0.14$ \\
Dec. & $1.20 \pm 0.97$ & $0.61 \pm 0.38$ & $4.27 \pm 3.11$ & $6.08 \pm 4.45$ & $0.64 \pm 0.29$ \\
Bottom & & & & & \\
Feb. & $1.54 \pm 0.17$ & $0.08 \pm 0.03$ & $2.36 \pm 1.26$ & $4.10 \pm 0.93$ & $0.22 \pm 0.10$ \\
Apr. & $1.58 \pm 0.44$ & $0.09 \pm 0.04$ & $0.93 \pm 0.19$ & $2.60 \pm 0.62$ & $0.21 \pm 0.06$ \\
Jun. & $2.31 \pm 1.04$ & $0.33 \pm 0.13$ & $0.68 \pm 0.80$ & $3.31 \pm 0.99$ & $0.28 \pm 0.06$ \\
Aug. & $3.82 \pm 0.61$ & $0.49 \pm 0.12$ & $3.52 \pm 0.38$ & $7.84 \pm 0.61$ & $0.50 \pm 0.02$ \\
Oct. & $6.14 \pm 1.33$ & $1.07 \pm 0.35$ & $3.92 \pm 0.89$ & $11.13 \pm 2.27$ & $0.67 \pm 0.17$ \\
Dec. & $1.33 \pm 0.69$ & $0.61 \pm 0.37$ & $3.87 \pm 2.70$ & $5.81 \pm 3.55$ & $0.45 \pm 0.21$
\end{tabular}

Values are means \pm standard deviations, DIN dissolved inorganic nitrogen, DIP dissolved inorganic phosphate

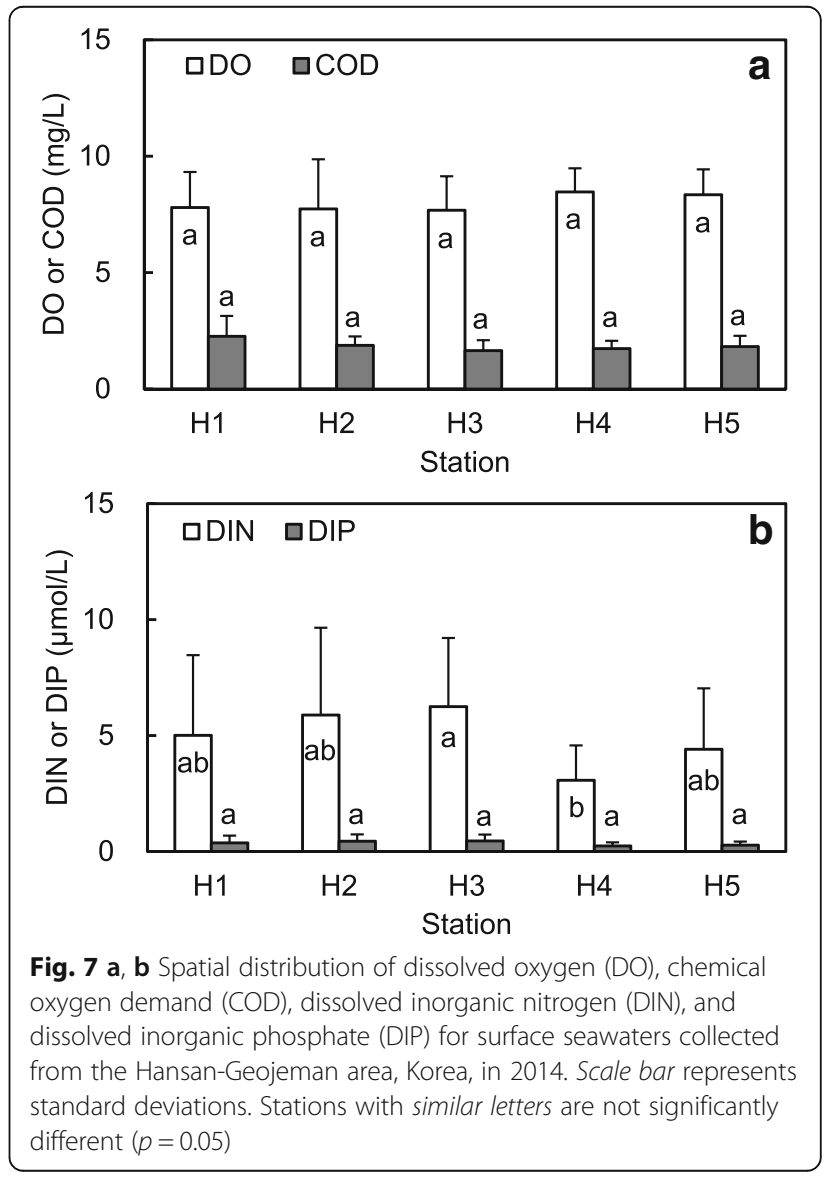


during August, which is close to inland pollution source (G1) with relatively high daily load of COD (Fig. 5a). COD concentrations tended to increase gradually from the middle of the sea area to the coastal regions; however, the differences of those among stations were not significant $(p=0.05)$ (Fig. 7a).

Oxygen-deficient water mass (ODW), which is defined as water containing less than the normal $3 \mathrm{mg} /$ L DO concentration (Pearson and Rosenberg 1978), occurs when the dead organisms and nutrient compounds sink to the bottom and are decomposed by bacteria, using the available dissolved oxygen (Rabalais et al. 2002; Middelburg and Levin 2009). The areas where ODW occurs have mainly semi-enclosed water bodies with poor exchange of water, such as the Hansan-Geojeman area. The Hansan-Geojeman area is representative of aquaculture regions of Korea, with active farming of oysters, fish, sea squirts, etc., and specially has a designated area for oysters. DO mean concentrations showed the largest difference in $\mathrm{Au}$ gust, and the lowest concentration of DO was also found in August at the bottom layer (Table 1). The lowest concentration of DO during August showed similar pattern in Jinhae Bay, Korea, reported by Kim et al. (2015). In Jinhae Bay, ODW began in June, which is the heavy rainfall season, and peaked in August, which is the high-temperature rainfall season. It began to weaken in September, at the start of the autumn season, and was already completely dissipated in December. But, it confirms that ODW was not shown in the surface and bottom waters of the Hansan-Geojeman area during all of the survey periods. The Chl- $a$ mean concentration was the highest in August at both layers, while April and June showed the lowest concentration in the surface and bottom layers, respectively (Table 1). Generally, the proliferation of phytoplankton, containing Chl-a, using DO has a direct effect on the fluctuation of DO concentration (Kim et al. 2015). Chl- $a$ distribution showed strong positive mutuality with DO in the summer month of August. Therefore, August showed the highest concentrations for COD and Chl- $a$ in the surface layer, whereas the lowest for DO in the bottom layer. In this study, all values of $\mathrm{pH}$, salinity, and DO were within $7-9,12-38$, and $\geq 80 \%$, respectively, of guide or mandatory levels for the quality required of shellfish waters set by the EU (EC 2006), with the exception of DO concentrations in August. The mean concentration of DIN and DIP were the highest in October at the bottom layer, while April and February showed the lowest mean concentration at the surface (Table 2). DIN concentrations at station 3 were significantly higher $(p<0.05)$ than those at station 4 ; however, the differences among other stations were not significant (Fig. 7b). The differences of DIP concentrations among stations were not significant $(p=0.05)$.

\section{Conclusions}

In this study, the mean daily loads and half-circle radii of FCs at each inland pollution source in the drainage basin of the Hansan-Geojeman area, including a designated area for oysters, ranged from $1.2 \times 10^{9}$ to $3.1 \times 10^{11} \mathrm{MPN} /$ day and 56.6 to $514.5 \mathrm{~m}$, respectively; the highest radius was found at station G4, which is a Seojeong stream with relatively high FC concentration. However, the pollutants could not be reached at the boundary line of the designated area thanks to the existing buffer zone, in which bacteria are diluted and reduced. The geometric mean level for FC of the seawater samples was the maximum in August. Therefore, FC counts had a seasonal variation and, specially, were detected higher after heavy rainfall before the sampling day. The FC concentrations at each station met the criteria of various countries for the approved area for shellfish.

The daily loads of COD of inland pollution sources showed higher values at stations (G1 and G6) with relatively high flow rate. The daily loads of DIN and DIP were relatively higher in September than in other months because of relatively high flow rates and/or concentrations of those. The highest concentrations for COD and Chl- $a$ were shown in the surface layer during August with high rainfall, whereas the lowest for DO in the bottom layer of the same month. Chl- $a$ distribution showed strong positive mutuality with DO in August. But, ODW was not shown in both of the surface and bottom waters during all survey periods. Therefore, this study shows that the concentrations of FC, COD, DO, and Chl- $a$ of seawaters were relatively detected higher in the summer season, with large rainfall, than in other seasons.

\section{Acknowledgements \\ This work was supported by a grant from the National Fisheries Research and Development Institute of Korea (R2015062).}

\section{Authors' contributions}

The manuscript is the result of ongoing collaboration and discussion between the authors. YCP carried out the study design and wrote the first draft. JSM added to and revised the manuscript. PHK, YJJ, KJL, MSK, KRG, SGP SJK, and JHY participated in sampling and analysis. All authors read and approved the final manuscript.

\section{Competing interests}

The authors declare that they have no competing interests.

\section{Author details}

${ }^{1}$ Southeast Sea Fisheries Research Institute, National Fisheries Research \& Development Institute, 397-68, Sanyang-iljuro, Sanyang-up, Tongyeong 650-943, Republic of Korea. ${ }^{2}$ Food Safety Research Division, National Fisheries Research \& Development Institute, 216, Gijang-haeanro, Gijang-up, Gijang-gun, Busan 619-705, Republic of Korea.

Received: 12 May 2016 Accepted: 19 May 2016

Published online: 07 June 2016 


\section{References}

APHA (American Public Health Association). Recommended procedures for the examination of seawater and shellfish. 4th ed. Washington D.C., USA: American Public Health Association; 1970. p. 1-47.

Avila MJ, Morinigo MA, Cornax R, Romero P, Borrego JJ. Comparative study of coliform-enumeration media from seawater samples. J Microbiol Meth. 1989; 9:175-93.

Chigbua P, Gordonb S, Strangec T. Influence of inter-annual variations in climatic factors on fecal coliform levels in Mississippi Sound. Water Res. 2004;38:4341-52.

Dorfman M, Sinclair Rosselot K. Testing the waters 2008: a guide to water quality testing at vacation beaches. Washington D.C., USA: Natural Resources Defense Council; 2008.

EC (European Commission). Commission Regulation (EC) No. 2073/2005 of 15 November 2005 on microbiological criteria for foodstuffs. 2005. Accessed 22 Jun 2015, http://eur-lex.europa.eu/LexUriServ/LexUriServ.do?uri=CONSLEG: 2005R2073:20071227:EN:PDF.

EC (European Commission). Directive 2006/113/EC of the European parliament and of the council of 12 December 2006 on the quality required of shellfish waters. 2006. Accessed 2 Sep 2015, http://eur-lex.europa.eu/legal-content/ EN/TXT/?uri=uriserv:OJ.L_.2006.376.01.0014.01.ENG.

Feldhusen $F$. The role of seafood in bacterial foodborne disease. Microbes Infect. 2000;2:1651-60

Geoje city. The 19th statistical yearbook of Geoje. 2014. Accessed 01 Jan 2016, http:// ebook.geoje.go.kr/src/viewer/main.php?host=main\&site=20150205_095443.

Ha KS, Yoo HD, Shim KB, Kim JH, Lee TS, Kim PH, et al. Evaluation of the influence of inland pollution sources on shellfish growing areas after rainfall events in Geoje bay, Korea. Kor J Fish Aquat Sci. 2011;44:612-21.

Kim YS, Lee YH, Kwon JN, Choi HG. The effect of low oxygen conditions on biogeochemical cycling of nutrients in a shallow seasonally stratified bay in southeast Korea (Jinhae Bay). Mar Pollut Bull. 2015;95:333-41.

KMFDS (Korea Ministry of Food and Drug Safety). Korea food code. 2015. Accessed 22 Jun 2015, http://fse.foodnara.go.kr/residue/RS/jsp/menu_02_01_01.jsp.

Lipp EK, Kurz R, Vincent R, Rodriguez-Palacios C, Farrah SR, Rose JB. The effects of seasonal variability and weather on microbial fecal pollution and enteric pathogens in a subtropical estuary. Estuaries Coast. 2001;24:266-76.

Middelburg JJ, Levin LA. Coastal hypoxia and sediment biogeochemistry. Biogeosciences. 2009;6:1273-93.

MOF (Ministry of Oceans and Fisheries). Marine environment process exam standard. Sejong, Korea: Ministry of Oceans and Fisheries; 2002. p. 43-268.

MOF (Ministry of Oceans and Fisheries). Korean Shellfish Sanitation Program (KSSP). Sejong, Korea: Ministry of Oceans and Fisheries; 2015. p. 1-110.

Mok JS, Song KC, Lee KJ, Kim JH. Variation and profile of paralytic shellfish poisoning toxins in Jinhae bay, Korea. Fish Aquat Sci. 2013;16:137-42.

Mok JS, Kwon JY, Son KT, Choi WS, Kang SR, Ha NY, et al. Contents and risk assessment of heavy metals in marine invertebrates from Korean coastal fish markets. J Food Prot. 2014a;77:1022-30.

Mok JS, Yoo HD, Kim PH, Yoon HD, Park YC, Lee TS, et al. Bioaccumulation of heavy metals in mussel Mytilus galloprovincialis in the Changseon area, Korea, and assessment of potential risk to human health. Fish Aquat Sci. 2014b;17:313-8.

Mok JS, Yoo HD, Kim PH, Yoon HD, Park YC, Lee TS, et al. Bioaccumulation of heavy metals in oysters from the southern coast of Korea: assessment of potential risk to human health. Bull Environ Contam Toxicol. 2015;94:749-55.

NZFSA (New Zealand Food Safety Authority). Animal products (specifications for bivalve molluscan shellfish). 2006. Accessed 22 Jun 2015, http://www. foodsafety.govt.nz/elibrary/industry/Animal_Products-Applies_Anyone.pdf.

Park KBW, Jo MR, Kim YK, Lee HJ, Kwon JY, Son KT, et al. Evaluation of the effects of the inland pollution sources after rainfall events on the bacteriological water quality in Narodo area, Korea. Kor J Fish Aquat Sci. 2012;45:414-22.

Pearson TH, Rosenberg R. Macrobenthic succession in relation to organic enrichment and pollution of the marine environment. Oceanogr Mar Biol Annu Rev. 1978;16:229-311.

Rabalais NN, Turner RE, Wiseman JR. Hypoxia in the Gulf of Mexico, a.k.a. "The dead zone". Annu Rev Ecol Syst. 2002;33:235-63.

Rabinovici SJ, Bernknopf RL, Wein AM, Coursey DL, Whitman RL. Economic and health risk trade-offs of swim closures at a Lake Michigan beach. Environ Sci Technol. 2004;38:2737-45.

Rippey SR. Infectious diseases associated with molluscan shellfish consumption. Clin Microbiol Rev. 1994;7:419-25.

Rose JB, Epstein PR, Lipp EK, Sherman BH, Bernard SM, Patz JA. Climate variability and change in the United States: potential impacts on water- and foodborne diseases caused by microbiologic agents. Environ Health Perspect. 2001;109:211-21.
Shim KB, Ha KS, Yoo HD, Lee TS, Kim JH. Impact of pollution sources on the bacteriological water quality in the Yongnam-Gwangdo shellfish growing area of western Jinhae bay, Korea. Kor J Fish Aquat Sci. 2012;45:561-9.

Statistics Korea. Korean Statistical Information Service (KOSIS). 2013. Accessed 20 Jun 2015, http://kosis.kr.

U.S. Food and Drug Administration (FDA). National Shellfish Sanitation Program (NSSP), Guide for the control of molluscan shellfish. 2013. Accessed 20 Jun 2015, http://www.fda.gov/Food/GuidanceRegulation/ FederalStateFoodPrograms/ucm2006754.htm.

Wu Y, Chen J. Investigating the effects of point source and nonpoint source pollution on the water quality of the East River (Dongjiang) in South China. Ecol Indic. 2013;32:294-304.

Yoo HD, Yoon HD, Kim PH, Mok JS, Ha KS, Lee HJ. Sanitary survey of shellfish growing area in Hansan-Geojeman area (2011-2013). Busan, Korea: National Fisheries Research and Development Institute; 2013. p. 1-103.

\section{Submit your next manuscript to BioMed Central and we will help you at every step:}

- We accept pre-submission inquiries

- Our selector tool helps you to find the most relevant journal

- We provide round the clock customer support

- Convenient online submission

- Thorough peer review

- Inclusion in PubMed and all major indexing services

- Maximum visibility for your research

Submit your manuscript at www.biomedcentral.com/submit
) Biomed Central 